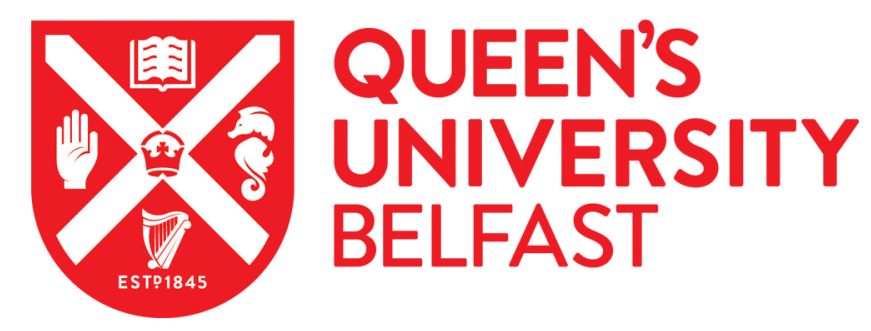

\title{
Conscientious objection in Greater Glasgow Health Board v. Doogan and others [2014] UKSC
}

Ó Néill, C. (2016). Conscientious objection in Greater Glasgow Health Board v. Doogan and others [2014] UKSC. Medical Law International, 15(4), 246. https://doi.org/10.1177/0968533216652003

Published in:

Medical Law International

Document Version:

Peer reviewed version

Queen's University Belfast - Research Portal:

Link to publication record in Queen's University Belfast Research Portal

Publisher rights

Copyright 2016 SAGE. This work is made available online in accordance with the publisher's policies. Please refer to any applicable terms of use of the publisher.

\section{General rights}

Copyright for the publications made accessible via the Queen's University Belfast Research Portal is retained by the author(s) and / or other copyright owners and it is a condition of accessing these publications that users recognise and abide by the legal requirements associated with these rights.

Take down policy

The Research Portal is Queen's institutional repository that provides access to Queen's research output. Every effort has been made to ensure that content in the Research Portal does not infringe any person's rights, or applicable UK laws. If you discover content in the Research Portal that you believe breaches copyright or violates any law, please contact openaccess@qub.ac.uk. 


\title{
CONSCIENTIOUS OBJECTION IN GREATER GLASGOW HEALTH BOARD V DOOGAN AND OTHERS [2014] UKSC 68
}

\begin{abstract}
This article considers the recent decision of the Supreme Court in Greater Glasgow Health Board v Doogan and Others, which concerns the definition of 'participate' in the context of abortion and the conscientious objection of healthcare professionals due to their religious beliefs. It is argued that the Supreme Court was correct in affirming the definition of 'participate' as articulated by Lord Keith in Janaway $v$ Salford Area General Authority. The protection of conscientious objection, under Article 9 of the European Convention on Human Rights, is considered. The discussion in this commentary, however, is limited to religious belief and does not consider the wider ambit of Article 9, such as non-religious philosophical beliefs.
\end{abstract}

\section{INTRODUCTION}

In the medical context, conscientious objection arises primarily in profoundly moral and often divisive situations such as abortion and assisted reproduction. Abortion, for example, can be at variance with the beliefs of some religious adherents, particularly those who believe that life begins at the moment of conception. The official position of the Catholic Church is as articulated by Pope John Paul II in Evangelium Vitae:

Abortion and euthanasia are thus crimes which no human law can claim to legitimize. There is no obligation in conscience to obey such laws; instead there is a grave and clear obligation to oppose them by conscientious objection. ${ }^{1}$

As a consequence, Catholic healthcare professionals may object to being involved in abortion procedures. The conscientious objection clause contained in $s 4$ of the Abortion Act 1967 is not confined to objections based on religious beliefs, but extends to those who object on the basis of non-religious moral or philosophical beliefs. In this short article, I examine the Supreme Court judgment in Greater Glasgow Health Board $v$ Doogan and Others (Doogan), ${ }^{2}$ which is the most recent and probably the most authoritative judicial statement on the scope of conscientious objection in medical law since the initial case of Janaway $v$ Salford Area General Authority (Janaway). ${ }^{3}$ After outlining the regulatory landscape for conscientious objection, I examine Janaway and then Doogan, offering some insights as to why Doogan was properly decided and what it means moving forward.

\section{LEGAL FOUNDATION, LIMITS AND DEVELOPMENT}

Section 4 of the Abortion Act 1967 provides the legal foundation for the conscientious objection of medical professionals. This provision states that no person shall be under any duty, whether by contract or by any statutory or other legal requirement, to

\footnotetext{
1 Pope John Paul II, Evangelium Vitae, available at: <http://www.vatican.va/holy father/john paul ii/encyclicals/documents/hf ipii enc 25031995 evangelium-vitae en.html (accessed 15 January 2015).

2 [2014] UKSC 68.

${ }^{3}$ Janaway v Salford Area General Authority [1989] AC 537 (HL).
} 
participate in any treatment authorised by this Act to which he has a conscientious objection, provided that in any legal proceedings the burden of proof of conscientious objection shall rest on the person claiming to rely on it. Subsection (2) states that nothing in s 4(1) affects any duty to participate in treatment which is necessary to save the life or to prevent grave permanent injury to the physical or mental health of a pregnant woman. Subsection (3) stipulates that in Scotland a statement on oath to the effect that one has a conscientious objection to participating in any treatment authorised by the Act is sufficient evidence for the purpose of discharging this burden of proof.

One can see that $s 4$ is quite categorical in stating that no person has a duty to 'participate' in an otherwise legal act of treatment to which they conscientiously object. However, the meaning of 'participate' is not clearly defined, and one's objection and refusal to participate imposes on other professionals the need to act, which has been equated to legislating morality for others:

To the doctor who complains that he wants to practise medicine without abortions, the answer must be that he can choose to engage in private practice, and thereby arrange his affairs by agreement with his patients. If he joins the NHS, he should remember the last word of the three, 'service', and serve. ${ }^{4}$

On the matter of private practice, to which the Abortion Act 1967 applies, the court in Barr $v$ Matthews stated that once a termination of pregnancy is recognised as an option, the doctor invoking the conscientious objection clause should immediately refer the patient to a colleague. ${ }^{5}$ Kennedy and Grubb argue that general practitioners are under a contractual obligation to arrange abortion services for their patients as part of their referral duties. ${ }^{6}$

Obviously, there are limits to s 4's operation; a doctor must perform an abortion in cases where it is necessary to save the pregnant woman's life, or to stop permanent injury to her physical or mental health. This means that if the patient is at risk of death or of physical or mental injury, the doctor cannot rely on conscientious objection to avoid acting. Having said that, in many cases another doctor will be in a position to undertake the abortion. ${ }^{7}$ Another limitation is that a doctor cannot use conscientious objection to refuse to advise a patient; she must refer the patient to another doctor in order to receive advice if she has a conscientious objection to abortions. ${ }^{8}$ (And of course, s 4 has no limiting effect on the duties owed to people who have had an abortion.)

The British Medical Association (BMA) has also offered guidance in respect of 'morally sensitive procedures', permitting doctors to excuse themselves as long as other doctors who do not conscientiously object are willing to undertake the procedure. ${ }^{9}$ In

\footnotetext{
${ }^{4}$ I Kennedy, Treat Me Right: Essays in Medical Law and Ethics (Clarendon Press: Oxford, 1998), at 29.

${ }^{5}$ Barr v Matthews (1999) 52 BMLR 217.

${ }^{6}$ I Kennedy and A Grubb, Medical Law, 3rd ed. (Butterworths: London, 2000), at 1446-1447.

7 J Herring, Medical Law and Ethics, (OUP: Oxford, $5^{\text {th }}$ ed, 2014) p. 306.

${ }^{8}$ Barr v Matthews, note 5.

${ }^{9}$ British Medical Association, Expression of Doctors' Beliefs, available at: http://bma.org.uk/practicalsupport-at-work/ethics/expressions-of-doctors-beliefs
} 
this way, the BMA seeks to balance doctors' freedom with the rights of patients to receive appropriate treatment in a suitably non-judgmental fashion. ${ }^{10}$ It highlights, however, the fact that a treating doctor's primary obligation is to her patient, and all requests for excusing oneself ought to be considered on the merits and realised in such a way that patients are not disadvantaged. ${ }^{11}$ The BMA regards Article 9 (freedom of conscience) of the European Convention on Human Rights (echr) to be important, but accepts that it is not an absolute right, a position which is supported by the General Medical Council (GMC). ${ }^{12}$

The benchmark case on conscientious objection was Janaway, ${ }^{13}$ an appeal from an employment arbitration wherein a Catholic secretary refused to type a referral letter for a possible abortion and was dismissed. She claimed a right to conscientiously object on the grounds that she would have been an accessory to the abortion. In other words, typing the letter was 'participation' under the Act that constituted counselling or procuring a termination. The Health Authority contended that the clause should only apply to those actually taking part in treatment actions. The Court of Appeal agreed, concluding that typing the referral letter did not assist in the abortion, but merely fulfilled her employment duties, and that it would not be a criminal act in the context of $s$ 1(1) of the Act. On further appeal to the House of Lords, per Lord Keith, dismissed Janaway's appeal, confirming that s 4 only applied to those "actually taking part in the treatment administered ... for the purpose of terminating a pregnancy."14 Lord Keith said that the term 'participate' should be given its natural meaning; if Parliament had intended to extend the notion of participation, it could have done so by referring to participation 'in anything authorised by this Act' instead of 'in any treatment [so] authorised' ${ }^{15}$

The Abortion Act 1967 was subsequently amended by the Human Fertilisation and Embryology Act 1990; the original limit of 18 weeks for an abortion was increased to 24 weeks. No changes were made in relation to the conscientious objection provision. Thereafter, questions arose about the scope of the right. Foster, for example, asked:

Is there really no distinction between a secretary typing a letter and a doctor referring? To assert that there is not downgrades the professional act of referral into a merely administrative business. Is not the initiation of the professional process that leads to the 'treatment' necessarily part of the 'treatment'? For all other purposes the doctor at the point of referral owes to the patient the duty of a doctor, not that of a secretary. ${ }^{16}$

He argued that the implementation of Article 9 ECHR in the Human Rights Act 1998, which occurred after Janaway, should support a refusal to refer as well as a refusal to treat, suggesting that the BMA assumes such a scope; its guidance states that doctors with a conscientious objection to abortion should make their views known to the

\footnotetext{
${ }^{10} \mathrm{lbid}$.

11 Ibid.

12 General Medical Council, Personal Beliefs and Medical Practice (2013), at: http://www.gmcuk.org/static/documents/content/Personal_beliefs and medical_practice.pdf

${ }^{13}$ Doogan, note 2.

14 Janaway, p 570.

15 Ibid, p 570.

${ }^{16}$ C Foster, 'A Lost Opportunity' (2008) 158 New Law Journal 889-890.
} 
patient and enable the patient to see another doctor without delay if that is the patient's wish. ${ }^{17}$ Foster also argued that it would be better if conscientious objection were reviewed by Parliament. He explains that:

Doctors, by and large, don't like doing abortions. This is generally not because of any deep-seated religious convictions. They just find the process distasteful, and get out of it if they can. This has led to a crisis in NHS abortion provision...The undoubted fact of doctors' distaste for abortion raises another issue which is properly the business of Parliament: the issue of conscientious objection. What about the doctor's right to choose? ${ }^{18}$

While one might argue that the doctor's right to choose is protected by s 4's balancing of rights, Miola regarded the law as more concerned with patient rights than with medical decisions, which could result in narrowing the doctor's ability to act in accordance with her conscience. ${ }^{19}$ In any event, further comprehensive judicial or legislative clarification were not forthcoming until Doogan.

\section{THE DOOGAN DECISION: STRAIGHT STATUTORY CONSTRUCTION}

Doogan concerned two Catholic midwives who worked in a Scottish labour ward and claimed that they were entitled to object to participate in abortions. Consequently, they did not take part in the treatment of certain patients. As the number of abortions sought increased, and the midwives became dissatisfied with the arrangements made to accommodate their objections, including a refusal to supervise support staff involved in abortions. Their employer, the Greater Glasgow Health Board, contended that the duties of delegation, supervision and support did not involve 'participating' in the treatment, and so rejected their grievance against so acting. The midwives sought judicial review of this decision. They were unsuccessful in the Outer House of the Court of Session, but an appeal to an Extra Division of the Inner House resulted in a wider interpretation of the scope of $s 4(1)$.

The Inner House differentiated the case from Janaway, saying that the duties of the midwives were far removed from those of a secretary, and that they were actually taking part in treatment administered in hospital for the purpose of terminating a pregnancy. ${ }^{20}$ It concluded:

In our view it is not only the actual termination which is authorised by the Act for the purposes of section 4(1), but any part of the treatment which was given for that end purpose. Section 4(1) allows an individual to object to participating in "any" treatment under the Act. In our view the right of conscientious objection extends not only to the actual medical or surgical termination but to the whole process of treatment given for that purpose..$^{21}$

\footnotetext{
17 Ibid.

18 Ibid.

19 J Miola, 'Making Decisions and Decision-Making: Conscience, Regulation and the Law' (2015) 23

Medical Law Review 263-282, at 269.

${ }^{20}$ Doogan v Greater Glasgow and Clyde Health Board [2013] SCIH 36.

21 Ibid, para 37.
} 
Ultimately, the Inner House noted that many people have strong religious or moral objections to abortion which ought to be respected, and so conscientious objection should extend to any involvement in the process of treatment. ${ }^{22}$

The Greater Glasgow Health Board appealed this decision to the Supreme Court, arguing that interpreting 'participate' as including everyone involved in the treatment team, even those whose role was not hands-on but only supervisory or supportive, would result in an improperly wide right of conscience; one that the health authorities would be unable to manage. ${ }^{23}$ The question put to the Supreme Court (SC) was the appropriate construction of 'to participate in any treatment authorised by this Act to which he has a conscientious objection' as contained in s 4(1) of the Abortion Act 1967. ${ }^{24}$

The unanimous judgment of the SC was given by Lady Hale, who stipulated that s 4 must be read in conjunction with $\mathrm{s} 1$, which sets out the conditions under which an abortion can lawfully be carried out. ${ }^{25}$ On the matter of its construction, she acknowledged that the objection can encompass any element of the treatment, saying:

[34] ... the course of treatment to which the petitioners may object is the whole course of medical treatment bringing about the termination of the pregnancy. It begins with the administration of the drugs designed to induce labour and normally ends with the ending of the pregnancy by delivery of the foetus, placenta and membrane. It would also, in my view, include the medical and nursing care which is connected with the process of undergoing labour and giving birth the monitoring of the progress of labour, the administration of pain relief, the giving of advice and support to the patient who is going through it all, the delivery of the foetus, which may require the assistance of forceps or an episiotomy, or in some cases an emergency Caesarian section, and the disposal of the foetus, placenta and membrane. In some cases, there may be specific aftercare which is required as a result of the process of giving birth, such as the repair of an episiotomy.

She went on to state and that the word 'participate' could nonetheless be given a broad or a narrow meaning. The midwives argued that adopting a narrow interpretation would excessively restrict the right to conscientiously object, and could unduly limit their potential job opportunities. The Greater Glasgow Health Board argued that to give a wide interpretation would put at risk the provision of a safe and

\footnotetext{
${ }^{22}$ Ibid. para. 38.

${ }^{23}$ A point made by M Neal, 'The Scope of Conscience-based Exemption in Section 4(1) of the Abortion Act 1967: Doogan and Wood v NHS Greater Glasgow Health Board' (2014) 22 Medical Law Review 409421 , at 412 .

${ }^{24}$ Doogan, para. 33. As such, the SC did not engage with the Article 9 ECHR right to respect for religious belief; it was held that such rights would be better served by recourse to Employment Tribunals: Ibid, para. 25-27.

${ }^{25} \mathrm{Ibid}$, para. 28.
} 
accessible abortion service, and might encourage employers to refuse to employ anyone who had objections to abortion based on conscience. Lady Hale noted the lack of data before the SC on these points, and made reference to Lord Diplock's speech in Royal College of Nursing of the United Kingdom v Department of Health and Social Security, ${ }^{26}$ to the effect that the policy of the Abortion Act 1967 is clear; it is to broaden the grounds upon which an abortion might lawfully be obtained, to ensure that abortion is carried out with proper skill and in hygienic conditions, and to provide such service within the NHS and approved clinics. The conscientious objection clause was "the quid pro quo for a law designed to enable the health care profession to offer a lawful, safe and accessible service to women who would previously have had to go elsewhere." 27 She concluded that the SC was not equipped to gauge what effect either a wide or a narrow construction of the conscience clause would have upon the delivery of that service, which may differ across regions, and so it could only make the best sense of what the section actually says. She therefore held as follows:

[37] ... On any view, it would not cover things done before the course of treatment began, such as making the booking before the first drug is administered. But a broad meaning might cover things done in connection with that treatment after it had begun, such as assigning staff to work with the patient, supervising and supporting such staff, and keeping a managerial eye on all the patients in the ward, including any undergoing a termination. A narrow meaning would restrict it to "actually taking part", that is actually performing the tasks involved in the course of treatment.

She concluded, in para. 38, that Parliament was more likely to have been conceived of the term 'participate' in a narrow way, and to not have had in mind the inclusion of administrative and managerial work such as the caterers, who provide food, and the custodians, who provide a clean environment. ${ }^{28}$ She then reviewed some of the tasks which midwives are contracted to perform, noting which ones might be conscientiously objected to under s 4(1), and ones which could not. The SC concluded by stating in no uncertain terms the conscientious objector is under an obligation to refer the case to a professional who does not share that objection; such is a necessary corollary of her duty of care towards the patient. ${ }^{29}$

\section{TWO ELEMENTS UNEQUALLY DISPOSED OF}

I would suggest that there are two critical elements of the case that are important. The first is the meaning of the word 'participate' in the conscientious objection clause of the Abortion Act 1967. This was directly and positively engaged with by the SC; indeed, it was at the centre of the Doogan judgment. On this semantic question, the SC took a contextual approach insofar as it drew on the purpose for which the statute was enacted (although it declined to examine the context so far as to consider broader

\footnotetext{
${ }^{26}$ Royal College of Nursing of the United Kingdom v Department of Health and Social Security [1981] AC 800 (HC).

${ }^{27}$ Doogan, note 2, para. 27.

${ }^{28} \mathrm{Ibid}$, para. 38.

${ }^{29} \mathrm{Ibid}$, para. 40.
} 
practice consequences for the midwives or the service). Ultimately, the SC endorsed a narrow meaning which limited the right to object to a direct and hands-on involvement in the procedure. Here, the increased number of abortions did not necessitate the midwives actively participating, but rather merely having more administrative and supervisory work (e.g., making calls to arrange medical terminations, or allocating ward staff to support the procedure) none of which were deemed direct enough to be a constituent factor in the performance of the abortion.

In supporting Janaway and specifying the meaning of participation, Doogan offers some useful clarity to both patients and practitioners around those aspects of professional practice which are direct and so conscience-dependent and those which are indirect and so necessary to undertake in abortions. For some with very deep religious beliefs, however, the decision likely remains unsatisfactory insofar as their conscience may still be offended, and this brings us to the second element of Doogan, which is the interaction between the statutory right to object (and therefore to avoid certain healthcare duties) and the protection or strengthening of this right by Article 9 ECHR. On this point, the SC said very little. ${ }^{30}$ It held that Article 9 is:

... a qualified right, which may be subject to "such limitations as are prescribed by law and necessary in a democratic society in the interests of public safety, for the protection of public order, health or morals, or for the protection of the rights and freedoms of others". Refusing for religious reasons to perform some of the duties of a job is likely (following ... Eweida $v$ United Kingdom ...) to be held to be a manifestation of a religious belief. There would remain difficult questions of whether the restrictions placed by the employers upon the exercise of that right were a proportionate means of pursuing a legitimate aim. The answers would be context specific and would not necessarily point to either a wide or a narrow reading of section 4 of the 1967 Act. $^{31}$

In the result, it deferred the question of the operation of Article 9 and appropriate accommodations to Employment Tribunals, giving no specific indication as to how those tribunals ought to deal with this issue.

Addison argues that Doogan improperly emasculated the conscience objection clause without any factual or legal basis to say that the narrow interpretation of participate was in line with Parliamentary intention, and that it is incorrect because it did not allow for (or even discuss) 'reasonable accommodation' as outlined in the Article 9 jurisprudence. ${ }^{32}$ This position might be overstated insofar as there is no apparent

\footnotetext{
30 Calling Article 9 ECHR a 'distraction': Ibid, para. 23.

31 Ibid, para. 23. In Eweida $v$ UK [2013] 57 EHRR 213, the wearing of religious emblems in an employment context was held to be protected under Article 9 ECHR, but, as a limited right, it was incumbent on employers to strike a fair balance between their wish for a corporate image and the employee's right to manifest her beliefs. The ECtHR confirmed that the freedom to manifest one's belief may be limited under Article 9(2) if necessary in a democratic society, including for the protection of the rights and freedoms of others.

${ }^{32} \mathrm{~N}$ Addison, 'Call the midwife I want an abortion', at http://religionlaw.blogspot.co.uk/2014/12/callmidwife-i-want-abortion-3.html [accessed 24 January 2014]. And in this, he has some support from Neal, note 23.
} 
change of the position of conscientious objection; the case replicates Janaway and hardens the narrow construction of participation without erasing the right of healthcare professionals to conscientiously object. Having said that, the GMC Guidance on personal belief and medical practice clearly situates conscientious objection within various ECHR rights (including, of course, the patient's right to be free from discrimination). ${ }^{33}$ The scope of the right to object and of the need for the employer to accommodate one's objection may be coloured by whether the right to conscientious objection is viewed as a private or a public issue, ${ }^{34}$ or perhaps an amalgam of both. ${ }^{35}$ On this view, we have the right to hold personal beliefs, and in many cases to act on them, but with a responsibility to function in a public domain in accordance with the rights expressed therefor. And of course, there must be some limits to the degree to which religious beliefs can be used to absolve a licensed practitioner from undertaking social or medical responsibilities. Either way, some instruction from the SC would have been welcome.

\section{CONCLUSION}

Overall, Doogan is a useful and largely satisfactory judgment which clarifies the meaning of 'participation' within conscientious objection. However, it does not engage with the foundation or scope of conscientious objection as completely as it might have in that it did not consider it in light of Article 9 ECHR. While Article 9 is a limited right, and limits on conscientious objection are contained in $s 4(2)$ of the Abortion Act 1967, some engagement with the operation of the limits (and of reasonable employer accommodation) would have been useful given that the right was finally again before the highest court in the land.

\footnotetext{
${ }^{33} \mathrm{GMC}$, note 9.

${ }^{34}$ As argued by J Montgomery, 'Conscientious Objection: Personal and Professional Ethics in the Public Square' (2015) 23 Medical Law Review 200-220.

${ }^{35}$ On this issue, there is some scholarly discussion about conscience, its relationship to integrity, internal dialogue, and external - and public - factors like court decisions: see C McLeod, 'Taking a Feminist Relational Perspective on Conscience' in J Downie and J Lewllellyn (eds), Being Relational: Reflections on Relational Theory and Health Law and Policy (Vancouver: University of British Columbia Press, 2011) 161-181.
} 